\title{
Presence of Carbonic Anhydrase III-like Protein in Shaggy Sea Raven, Hemitripterus villosus
}

\author{
Rok Eun Kweon and Kang Hee Kho*
}

Department of Aquatic Biology, College of Fisheries and Ocean Sciences, Chonnam National University, Yeosu 550-749, Korea

Received January 1, 2014 /Revised January 17, 2014 / Accepted February 7, 2014

\begin{abstract}
Carbonic anhydrase isozymes (CAs) are widespread zinc-containing metalloenzyme family. The enzyme catalyzes the reversible interconversion of $\mathrm{CO}_{2}$ and $\mathrm{HCO}_{3}$. This reaction is the main role of CA enzymes in physiological conditions. CA III, one of the CA isozymes, has been identified in many tissues. It is distinguished from the other isozymes by several characteristics, particularly by a lower specific activity and by its resistance to acetazolamide. However, the physiological function of CA III in fish is unknown. In this study, we examined the detection of CAs in the Shaggy sea raven Hemitripterus villosus, using SDS-PAGE, isoelectric focusing (IEF), and western blot analysis. We detected a significant protein band with molecular weight about $30 \mathrm{kDa}$ from the tissues of $H$. villosus by SDS-PAGE and western blotting. A specific band of CA III with pI 7.0 was detected by IEF and western blotting in gill and muscle. The immunoreaction of anti-CA III expressed in the gill of $H$. villosus was much stronger than other tissues. One explanation for this result is that the fish gill is the only organ that is exposed to the external environment and that plays an important role in acid-base relevant ion transfer, the transfer of $\mathrm{H}^{+}$and/or $\mathrm{HCO}_{3}{ }^{-}$, for the maintenance of systemic $\mathrm{pH}$. This is the first report on the identification of a carbonic anhydrase III-like protein from $H$. villosus.
\end{abstract}

Key words : Carbonic anhydrase, fish, gill, isozyme, shaggy sea raven

\section{서 론}

Carbonic anhydrase $(\mathrm{CA})$ 는 동 - 식물 및 미생물 등에 다양 하게 존재하는 금속성효소(Metalloenzyme)로서 $\mathrm{CO}_{2}$ 가 hydration 되어 $\mathrm{H}^{+}$과 $\mathrm{HCO}_{3}^{-}$을 생산하는 가역적인 반응을 촉매 하는 역할을 한다는 것이 알려져 있다. 이는 동물에서는 monomer의 형태로, 식물에서는 hexamer 또는 octamer 의 형태로 존재하여 호흡, 산염기 평형, 이온수송, 광합성, 빼 재흡수 등 과 같은 생리학적인 과정에서 중요한 역할을 수행한다고 알려 져 있으며[16], 특히 어류에서는 $\mathrm{pH}$ 조절과 기체 균형, 석회화, 삼투조절, 이온조절과 질소대사로부터의 노폐물 제거와 같은 과정에서 핵심적인 역할을 한다고 밝혀졌다[14].

이러한 CA의 Isozymes (CAs) 중의 하나인 CA III는 생물체 내 다양한 조직 내부에서 확인되었다[3]. 일반적인 CA isozyme와는 다르게 구분되는CA III만의 몇 가지 특징이 존재하 는데, 비교적 낮은 특이적 활성과 acetazolamide에 대한 저항 성이 그것이다[3, 7]. CA III의 생리학적 기능에 대해서는 아직

\footnotetext{
*Corresponding author

Tel : +82-61-659-7169, Fax : +82-61-750-3257

E-mail : kkh@chonnam.ac.kr

This is an Open-Access article distributed under the terms of the Creative Commons Attribution Non-Commercial License (http://creativecommons.org/licenses/by-nc/3.0) which permits unrestricted non-commercial use, distribution, and reproduction in any medium, provided the original work is properly cited
}

확실히 알려진 바는 없지만 주로 산화적 스트레스, 과산화 지 방질, 단백질의 산화, 세포의 항상성의 방해, 세포의 죽음 및 병리학적인 상처 등으로부터 세포를 보호하는 역할을 수행하 는 것으로 알려져 있다. 이중 산화적 스트레스(Oxidative stress)는 친산화성물질(Prooxidants)과 항산화성물질(Antioxidants) 간의 균형이 무너져 산화적 손상이 발생하는 경우를 말한다. 즉, 산화제로 작용하는 활성산소종이 체내 항산화방 어계와 균형이 깨지면서 발생하는 산화적 손상을 의미하며 이는 $\mathrm{DNA}$ 손상, 세포 내 유리칼슘과 철 이온 농도 증가, 생체 막의 이온 수송계 손상, 단백질 손상, 지질과산화를 포함한 세포대사에 심각한 문제를 일으키고 있어 현재 생물학적으로 많은 연구가 진행되어 있다.

이러한 산화적 스트레스와 CA III의 연관성은 수계환경에 의존하는 해양생물의 경우 수온, 용존산소의 결핍, $\mathrm{pH}$ 의 변 화, 수질오염 및 어획 등으로 스트레스를 받기 때문에 매우 크다고 할 수 있다. 특히 어류는 스트레스를 받게 되면 1차적 으로 내분비계와 신경계가 자극을 받고 2차적으로 삼투압 조 절 이상[15], 대사 에너지 증가[1], 3차적으로 성장감소[6], 생 식억제 [4], 면역력 저하[12, 13]가 발생하여 결국 감염률 및 폐 사의 비율이 증가하게 된다. 그에 따라서 현재 항산화단백질 인 CA III에 관련된 많은 연구들이 보고되고 있으나 대부분 의학분야에 국한되어 있고 실험대상도 인체 혹은 인간과 근연 에 있는 쥐나 토끼 또는 유전자가 단순한 효모와 박테리아를 중심으로 한 연구가 대부분이다[10]. 최근 국내에서는 문치가 자미[9], 농어, 무지개송어[10]를 대상으로 한 연구가 이루어져 
있으나 아직 어류와 해양생물에 대해서는 자료가 부족한 실정 이다.

이와 같이 어류가 환경적 스트레스에 반응하여 생체 내에서 항산화 단백질인 CA III의 발현량이 증가하기 때문에 어류 내 CA III의 존재유무와 발현량을 측정하여 어류와 해양생물 의 수계환경 변화를 측정하는 지표로 활용할 수 있다고 사료 된다[10].

따라서 본 논문에서는 항산화 단백질인 CA III 연구의 기본 적인 자료획득을 위해 최근 양식품종 다양화와 연안어장의 어족자원 증대를 위해 지역 특성에 적합한 새로운 대체 양식 어종으로 알려져 있으며, 다른 어종과 달리 아가미로 해수에 녹아 있는 산소를 흡수하고 체내의 이산화탄소를 수중에 배출 하면서 피부로 가스교환을 하는 종인 삼세기(Shaggy sea raven, Hemitripterus villosus)를 실험재료로 하여 CA III의 존재를 파악하고 그 발현양상을 관찰하고자 SDS-PAGE와 IEF 전기영 동법을 이용하여 CA III 단백질을 분리하고, Western blot analysis를 시행하여 발현정도를 확인하였다.

\section{재료 및 방법}

\section{실험어 및 조직준비}

본 연구에 사용된 삼세기는 2010년 10월과 11월 사이에 전 라남도 여수시 연안 해역에서 어획된 수컷(체장 $23 \pm 1 \mathrm{~cm}$ ) 3 마 리를 해수가 채워진 아이스박스에 넣고 어류 이동에 따른 스 트레스를 최소화하기 위해서 차광막을 설치하여 산소부족에 대비하여 에어레이션을 사용하면서 전남대학교 생리학 실험 실로 수송하였다.

수송 후 바로 마취를 하지 않은 상태에서 절개하여 조직(혈 액, 근육, 신장, 심장, 간, 장, 아가미)를 적출 후 바로 액화질소 에 담가 급속 동결시켜 사용 전까지 $-80^{\circ} \mathrm{C}$ 에 보관 하였다.

\section{단백질의 분리}

각 조직 $0.3 \mathrm{~g}$ 에 $900 \mu \mathrm{l}$ 의 ice-cold Tris buffer $(10 \mathrm{mM}, \mathrm{pH}$ 7.2)를 더하여 얼음 속에서 homogenizer로 분쇄하여 균질액을 만들었다. 균질액은 $4^{\circ} \mathrm{C}$ 에서 저속으로 $(3,000 \times \mathrm{g}) 3$ 분 동안 3 회 원심분리하여 상층액을 분리한 다음 분리한 상층액을 다시 $4{ }^{\circ} \mathrm{C}$ 에서 고속으로 $(14,000 \times \mathrm{g}) 90$ 분 동안 2 회 원심분리하여 상 층액과 pellet을 구분하였다. Pellet의 부피는 $200 \mu$ 로 준비하 였다.

\section{가용성 단백질의 농도 분석}

가용성 단백질의 농도는 BSA를 사용한 Bradford [2]의 방 법을 사용하여 분광광도계로 정량화하였다. 세포질 추출물 각 $100 \mu \mathrm{l}$ 에 단백질 정량용 Bradford 시약(Bio-rad, USA) $50 \mu \mathrm{l}$ 를 가하고 발색 반응시켜 $590 \mathrm{~nm}$ 에서 흡광도를 측정하며 표준 단백질 BSA (Bovine Serum Albumin, Sigma-Aldrich, USA)
와 시료 대신 증류수를 넣은 바탕 시험구와 함께 동일한 방법 으로 흡광도를 측정하고 표준곡선을 작성하여 단백질 농도를 계산하였다.

\section{항체의 제조}

항체의 제조는 Chai et al. [5]의 방법을 이용하여 쥐 간에서 추출한 carbonic anhydrase III를 정제하여 항원으로 이용하였 으며 정제된 항원 $100 \mu \mathrm{g}$ 에 보조시약인 Freund's complete adjuvent $(0.5 \mathrm{ml})$ 를 섞어 여섯 달이 된 New Zealand rabbit에 주사하고 2주 후 같은 방법으로 보강 접종하여 항체 생성도가 1:500에 달했을 때 토끼 귀에서 채혈하여 다량의 항체(anti-CA III $\mathrm{IgG})$ 를 분리하였다.

\section{SDS-PAGE와 Isoelectric focusing (IEF)}

SDS-PAGE (Sodium dodecyl sulfate-polyacrylamide gel electrophoresis)는 Laemmli [11]의 방법을 이용하여 $12 \%$ polyacrylamide separating gel과 5\% polyacrylamide stacking gel로 구성된 discountinuous system에 전기영동하여 분리하 였다. 세포질 단백질에 sample buffer $(1 \mathrm{M}$ Tris- $\mathrm{HCl}, \mathrm{pH}$ 6.8; 2-\% Glycerol, Fluka, Switzerland; 2\% $\beta$-mercaptoethanol, Hanawa, Japan; $1 \%$ bromophenol blue, Sigma-Aldrich, USA; $10 \%$ SDS, Sigma, USA)를 4:1 (v/v)로 eppendorf tube에 넣고 혼합한 후 $100^{\circ} \mathrm{C}$ 에서 3 분간 열처리를 한 다음 표준단백질과 함께 각각의 조직의 상층액이 단백질농도 $4 \mu \mathrm{l}$ 를 포함하도록 계산하여 알맞은 양으로 넣고 Power pack universal power supply (Bio-rad, USA)에 연결 후 loading 하여 단백질을 음이 온 하전시켰다. 이 때 표준단백질인 phosphorylase B (MW 103,034), bovine serum albumin (MW 80,664), ovalbumin (MW 49,491), carbonic anhydrase (MW 36,545), soybean trypsin inhibitor (MW 28,82), lysozyme (MW 19,445)을 함유 하고 있는 SDS-Standards (Bio-rad, USA)를 사용하여 전체 시 료가 gel 유리판 하단에 하전될 때까지 $25 \mathrm{~mA}$ 에서 30 분 동안 2회로 시행하고 육안으로 식별하며 전기영동을 진행하였다.

IEF (Isoelectric focusing)는 세포질 단백질을 시료로 사용 하여 수평형 slab gel (4.5\% acrylamide, $1 \%$ ampholyte)에 표 준단백질과 함께 각각 $10 \mu \mathrm{l}$ 를 넣고 $\mathrm{pH}$ 3.5 9.5에서 loading 하였다. 이 때 표준단백질인 cytochrome C (pI 9.6), lentil lectin (pI 8.0), human hemoglobin C (pI 7.5), human hemoglobin A (pI 7.1), equine myoglobin (pI 7.0), human carbonic anhydrase (pI 6.5), bovine carbonic anhydrase (pI 6.0), $\beta$ -lactoglobulin B (pI 5.1), phycocyanin (pI 4.65)을 함유하고 있는 IEF Standards (Bio-rad, USA)을 사용하였다.

\section{Electric transfer}

전기영동 후 분리된 각각의 gel을 polyvinylidene fluoride (PVDF) membrane (Millipore, USA)에 전이시키기 위해 gel 

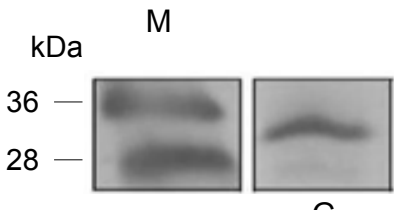

G

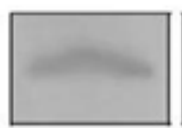

B

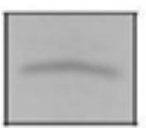

I

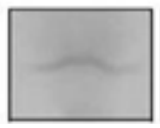

L

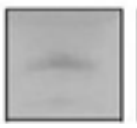

K

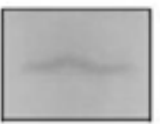

M

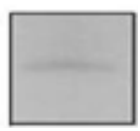

$\mathrm{H}$

Fig. 1. Presence of Carbonic Anhydrase III-like protein in tissue of Shaggy sea rave. SDS-PAGE and Western blot analysis of cytosolic protein from various tissues of Shaggy sea raven. (B, Blood; M, Muscle; K, Kidney; H, Heart; L, Liver; I, Intestine; G, Gill)

과 동일한 크기의 PVDF membrane을 transfer buffer $(25 \mathrm{mM}$ Tris-base, Sigma, USA; 192 mM Glycine, Sigma-Aldrich, USA; $20 \% \mathrm{MeOH}$, Hayman, England)에 10분간 처리하고 Transfer blot semi-dry cell (Bio-rad, USA)로 $25 \mathrm{~mA}$ 에서 25 분간 단백질을 전이하였다.

\section{Western blot analysis}

전이된 membrane을 TBST (Tris Buffered Saline with Tween 20, Sigma-Aldrich, USA)로 세척 후 7.5\% skimmed milk를 포함한 TBST로 실온에서 1 시간 동안 반응시켰다. 이 후 7.5\% skimmed milk를 포함한 TBST에 primary antibody 를 넣고 실온에서 2 시간 동안 반응시킨 다음 TBST로 10 분간 3 번 수세하고 secondary antibody (Anti-Rabbit IgG, SigmaAldrich, USA)를 실온에서 2시간 동안 반응시킨 후 TBST로 10 분간 3번 수세하였다. 이후 각 lane 의 band들은 발색시약 인 BCIP/NBT (5-bromo-4-chloro-3-Indolyl Phosphate / Nitro blue Tetrazolium, Sigma-Aldrich, USA)에 10 15분간 반응시키고 발색된 밴드를 이미지스캐닝 하였다.

\section{결과 및 고찰}

Carbonic Anhydrase (CA)는 아연(Zinc) 이온이 함유된 금 속성 효소로서 $\mathrm{CO}_{2}$ 의 hydration과 bicarbonate의 dehydration을 촉매하는 기능을 하기 때문에 생물체에서 호흡, 산. 염기 평형, 이온 수송, 광합성, 뼈 재흡수 등과 같은 생리학적 인 과정에서 중요한 역할을 한다[16]. 어류에서는 CA가 $\mathrm{pH}$ 조절, 석회화, 삼투조절, 이온조절, 질소대사로부터 노폐물 제 거 등과 같은 역할을 수행하는 것으로 알려져 있다[14]. 특히 Carbonic Anhydrase Isozymes (CAs) 중 CA III는 항산화단 백질로서 다른 동위효소들과 구별되는 특징을 갖는다. 이러한 CA III는 생물체 내에서 산화적 스트레스, 과산화 지방질, 단백 질의 산화, 세포의 항상성 저해, 세포의 죽음, 병리학적 상처 등의 많은 과정으로부터 세포를 보호하는 역할을 수행한다.

그러므로 본 연구에서는 연안 어장의 어족자원 증대를 위한 지역특성에 적합한 새로운 양식 대체 어종이면서 아가미 호흡 과 피부호흡을 병행하여 호흡량이 많은 삼세기를 실험재료로 하여 항산화 단백질인 CA III의 존재여부를 관찰하였다.

삼세기의 혈액, 근육, 신장, 심장, 간, 장, 아가미를 적출하여 각각의 세포질 단백질을 Bradford법으로 분석하여 가용성 단
백질 농도를 비교하였으며, 그 후 각 조직의 세포질 단백질을 정제하여 SDS-PAGE와 IEF로 단백질을 분리한 후 Western blot analysis를 통하여 CA III의 발현여부를 확인하였다.

SDS-PAGE와 Western blot analysis 결과, 삼세기의 각 조 직에서 $\mathrm{CA} \mathrm{III의} \mathrm{분자량인} 30 \mathrm{kDa}$ 의 위치에서 band가 확인되 었으며(Fig. 1), 이는 쥐와 가자미에서 추출한 $\mathrm{CA} \mathrm{III의} \mathrm{분자량}$ 과 일치하였다 $[8,9]$. 또한 SDS-PAGE 시행 결과에 근거하여 삼세기의 아가미와 근육 조직에서 $\mathrm{CA} \mathrm{III의} \mathrm{pI}$ 값을 확인하기 위해 IEF와 Western blot analysis를 시행한 결과 두 조직 모두 pI 7.0 부근에서 band의 형성이 관찰되었다(Fig. 2, Fig. 3).
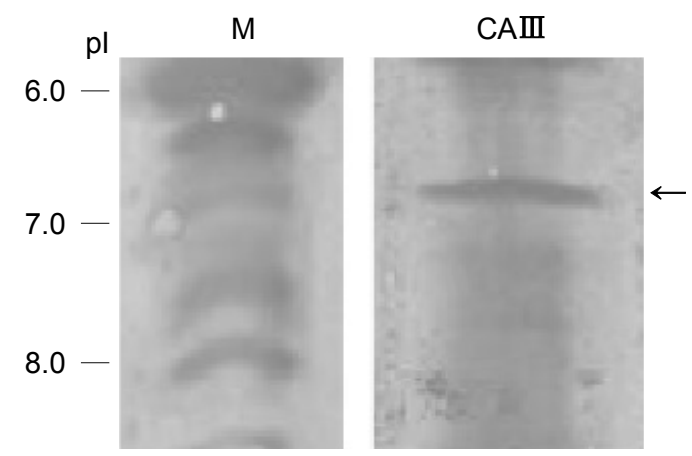

Fig. 2. Isoelectric focusing and western blot analysis of carbonic anhydrase III-like protein in the muscle of Shaggy sea raven. $\mathrm{M}$, pI Marker; CA III, immunostaining with anti-CA III IgG.
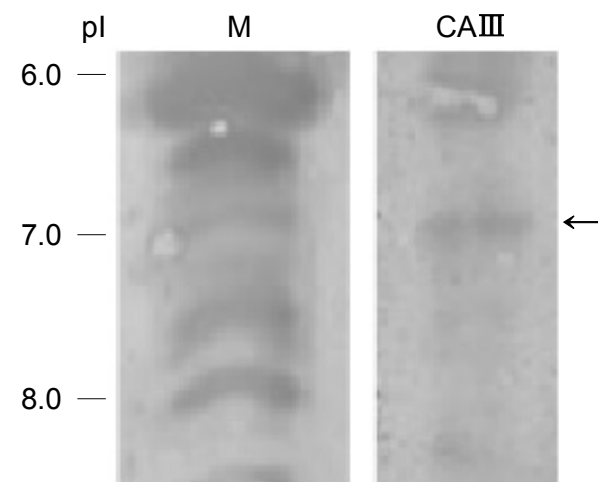

Fig. 3. Isoelectric focusing and western blot analysis of carbonic anhydrase III-like protein in the gill of Shaggy sea raven. M, pI Marker; CA III, immunostaining with anti-CA III IgG. 
SDS-PAGE와 IEF 실험 결과 삼세기의 각 조직에서 CA III 의 전반적인 발현정도가 아가미조직에서 상대적으로 우세한 양상이 확인되었다. 이는 어류인 삼세기의 체내기관 중 아가 미만이 유일하게 외부와 직접 접촉이 가능한 조직으로서 활성 산소에 대한 손상을 최소화하기 위한 것으로 사료된다.

또한 삼세기의 각 조직에서 CA III의 발현양상은 각각 다르 지만 존재유무는 파악되는 것에 근거하여 CA III가 생리학적 과정에서 중요한 역할을 하는 것으로 추측된다.

그러므로 본 연구결과는 어류 및 해양생물과 환경적 스트레 스와의 비교분석에 대한 기본적인 데이터를 제공했다는 것에 있어서 그 의의가 있다고 할 수 있다.

\section{References}

1. Barton, B. A. and Schreck, C. B. 1987. Metabolic cost of acute physical stress in juvenile steelhead. Trans Am Fish Soc 116, 257-263.

2. Bradford, M. M. 1976. A rapid and sensetive method for the quantification of microgram quantities of protein utilizing the principle of protein-dye binding. Reprod 12, 133-149.

3. Cabiscol, E. and Levine, L. 1995. Carbonic Anhydrase III ; Oxidative modification in vivo and loss of phosphatase activity during aging. J Biol Chem 270, 14742-14747.

4. Carragher, J. F. and Sumpter, J. P. 1990. The effect of contisol on the secretion of sex steroids from cultured ovarian follicles of rainbow trout. Gen Comp Endocrinol 77, 403-407.

5. Chai, Y. C., Jung, C. H., Lii, C. K., Asharf, S. S., Hendrich, S., Wolf, B., Sies, H., and Thomas, J. A. 1991. Identification of an abundant S-thiolated rat liver protein as carbonic anhydrase III; characterization of S-thiolated and dethiolation reactions. Arch Biochem Biophys 284, 270-278.

6. Clarke, W. C., Shelbourne, J. R. and Brett, R. J. 1981. Effects of artificial photoperiod cycles, temperature and salinity on growth and smolting in underyearling coho (Oncorhynchus kisutch), Chinook (Oncorhynchus tshawytscha) and sockeye
(Oncorhynchus nerka) salmon. Aquaculture 22, 105-116.

7. Eriksson, M., Karlsson, J., Ramazanov, Z., Gardestöm, P. and Samuelsson, G. 1996. Discovery of an algal mitochondrial carbonic anhydrase: molecular cloning and characterization of a low $\mathrm{CO}_{2}$ induced polypeptide in Chlamydomonas reinhardtii. Proc Natl Acad Sci USA 93, 12031-12034.

8. Kazuo, T. S., Junko, T. and Yasumitsu, O. 1999. Identification of the zinc-binding protein specifically present in male rat liver as carbonic anhydrase III. Chem Biol Interact 122, 185-197.

9. Kho, K. H. and Choi, K. S. 2005. Presence of Carbonic Anhydrase III in Liver of Flounder, Limanda yokohamae. Food Sci Biotechnol 14, 551-553.

10. Kwak, D. J., Choi, K. S., Han, K. H. and Kho, K. H. 2011. Discovery of Carbonic Anhydrase Isozyme in Sea bass, Lateolabrax japonicas and rainbow trout, Oncorhynchus mykiss. J Korean Soc Appl Biol Chem 54, 649-652.

11. Laemmli, U. K. 1970. Cleavage of structural proteins during the assembly of the head of bacteriophage T4. Nature 277, 680-685.

12. Maule, A. G., Schreck, C. B. and Kattari, S. L. 1987. Changer in the immune system of coho salmon Oncorhynchus kisutch during the parr-to-smolt transformation and after implantation of cortisol. Can J Fish Aquat Sci 44, 161-166.

13. Pickering, A. D. 1992. Rainbow trout husbandry : management of the stress response. Aquaculture 100, 125-139.

14. Raisanen, S. R., Lehenkari, P., Tasnen, M., Rahkila, P., Harkonen, L. P. and Vaananenm, H. K. 1999. Carbonic anhydrase III protects cells from hydrogen peroxide-induced apoptosis. FASEB J 13, 513-522.

15. Robertson, L., Thomas, P. and Arnold, C. P. 1988. Plasma cortisol and secondary stress responses of cultured red drum (Sciaenops cellatus) to several transportation procedure. Aquaculture 68, 115-130

16. Smith, K. S. and Ferry, J. G. 2000. Prokaryotic carbonic anhydrase. FEMS Microbiol Rev 24, 335-366. 
초록 : 삼세기(Shaggy sea raven, Hemitripterus villosus)의 carbonic anhydrase III에 관한 연구 권록은 · 고강희*

(전남대학교 수산해양대학 양식생물학전공)

본 논문에서는 삼세기(Shaggy sea raven, Hemitripterus villosus)를 실험 재료로 선택하여 Carbonic Anhydrase Isozymes (CAs) 중의 하나인 CA III에 대한 연구를 SDS-PAGE, Isoelectric Focusing (IEF), Western blot analysis 의 방법을 통하여 진행하였다. SDS-PAGE와 Western blot 결과 삼세기 아가미, 혈액, 장, 간, 신당, 근육, 심장조직 에서 CA III의 분자량인 $30 \mathrm{kDa}$ 의 band가 확인되었다. 삼세기의 근육과 아가미에 대한 등전점 전기영동(IEF)과 Western blot analysis 결과 pI 7.0 부근에서 band가 형성되는 것을 확인할 수 있었다. 특히 SDS-PAGE와 IEF 실험 결과 삼세기의 아가미 조직에서 CA III의 발현량이 다른 조직들에 비하여 우세하게 나타났다. 이는 아가미가 다른 조직들과 달리 어류의 생체기관 중 유일하게 외부와 직접 접촉이 가능한 조직으로서 활성산소에 대한 손상을 최 소화하기 위한 것으로 사료된다. 